\title{
CITY BRAND IMAGE FORMATION BY URBAN HERITAGE INITIATIVES*
}

\author{
Migle Černikovaite** \\ Žaneta Karazijiene $\dot{e}^{* * *}$
}

Received: 24. 2. 2020

Preliminary communication

Accepted: 15. 6. 2020

UDC 659.122:711.4](474.5)

DOI https://doi.org/10.30924/mjcmi.25.s.4

\begin{abstract}
Ab
In today's world, as cities compete in the marketplace, strategies for creating a city brand image are often shaped solely to meet the aspirations of profit, business development, and awareness. The preservation of culture, historical, and urban heritage remains important only in urban development strategies and not in actual development actions. The truth is, the image of a city is shaped by different historical, political, demographic, sociological, and economic factors which make up what we perceive as the brand image of a city. However, one of the most noticeable elements of the brand image of a city is the urban heritage based on national traditions. The aim of this article is to evaluate the effects of urban heritage initiatives in the creation of the brand image of the city of Vilnius. Research
\end{abstract}

\section{INTRODUCTION}

In the age of globalization, the environment is extremely dynamic, rapidly changes, and those changes have led to one of the fundamental challenges: the competition between cities at the regional, national or even international level. Cities compete for the atten- methods used in this article are qualitative content analysis and expert semi-structured interviews. Main conclusions stimulate debate, hesitation and criticism from communities and city researchers for using new heritage object and culture initiatives in order to create the brand image of Vilnius. The influence of urban heritage is inevitable when modelling the brand image of Vilnius, but there are no effective strategies to deal with the new urban heritage initiatives by creating the brand image of Vilnius yet.

Keywords: city brand image, urban heritage initiatives, modernization, heritage sites, stakeholders, urban neighbourhoods, business development.

tion of stakeholders, i.e. potential tourists, investors, residents, etc. However, many authors note the negative effects of such an economic competition, as cities are becoming uniform, as created environment, infrastructure and amenities are becoming similar. Due to these reasons, cities are forced to discover new ways of differentiating them-

\footnotetext{
* This research was carried out within the Erasmus+ Programme of the European Union in the framework of Strategic Partnership project "Cultural Studies in Business" (ERASMUS 2018-1-IT02-KA203-048091). The paper reflects only the views of the authors, and the European Commission cannot be held responsible for any use, which may be made of the information contained therein.

** Miglè Černikovaité, lecturer, Department of Creative Communication, Faculty of Creative Industries, Vilnius Gediminas Technical University, Lithuania, Trakų g. 1; LT-01132, Vilnius, Email: miglec@yahoo.com, ORCID: https://orcid.org/0000-0002-8307-3242

*** Žaneta Karazijiené, Assoc. Professor, Department of Economics Engineering, Faculty of Business Management, Vilnius Gediminas Technical University, Lithuania, Saulètekio al. 11, 10223 Vilnius, Email: zaneta.karazijiene@ vgtu.lt, ORCID: https://orcid.org/0000-0001-7979-6547
} 


\section{Journal of Contemporary Management Issues}

selves from others in order to present their uniqueness.

In creating the image of modern cities, striving to be attractive is a priority, and often the attributes of urban uniqueness that are not considered contemporary are often overlooked, recklessly or deliberately omitted in the image-building strategies.

Many authors who analyze the processes of urban image formation and change, emphasize the influence of environmental urban projects on the overall image of the city. They point out the heritage sites as cornerstones, revealing the city's history, culture and perspectives. Heritage management is a complex and demanding task; when successful, it will always show (either in the forefront or in the background) the background multidisciplinary approach. Heritage interpretation, not surprisingly, very often plays a key role in this process (Šćitaroci et al., 2019). However, those cities that do not have clear attributes that are well-recognizable around the world have difficulties in evaluating what heritage objects are valuable, what needs to be preserved and represented, and what not to show or even drastically convert: change the appearance, purpose, or even destroy the objects.

Anholt (2007), who studied widely the urban components that determine the image, emphasizes the spontaneous formation of the image through the individual's personal experience. Langer (2000) and van Ham (2008) explored the historical aspects that contribute to the city image creation, highlighting the importance of historical events. Warnaby and Medway (2013) explored the practical tools for urban image formation: strategies and effectiveness of the city image. Rainisto (2003) and Liljedahl (2010) introduced a system of factors guaranteeing the formation of the city image and the main criteria of the city as an attractive object. Kavaratzis (2005) also analyzed the problems of the city image. Kalandides (2015) and Jo Hatch (2013) extensively addressed urban image creation failures, image creators' errors, and ineffective solutions. Kavaratzis and Kalandides (2015) discussed the necessity of urban modernization and how such a process affects individuals and the environment in general. Slater and Tonkiss (2001) highlighted the contraposition between modernity and history, and the promotion of cultural heritage.

Despite these studies, the influence of the urban heritage on the image of the city and its development is still under-researched in scholars' works. The image of Vilnius as a modern city has been chosen recently, but urban processes taking place in the city have so far been poorly discussed in the context of such an image. Namely, the following aspects will be analyzed in this article.

The aim of the article is to analyze the impact of heritage initiatives on the image of the city (investigating the case of Vilnius). The article presents an analysis of the relationship between the city image and urban heritage, based on the results of a qualitative research. Systematically collected data can be used to assess the impact of elements of the urban environment to the image of the city, not only in the case of Vilnius, but also to study patterns in other cities. The article formulates the principles that justify the tasks of improving the city image. The analysis of scientific literature and research results can be useful in solving practically the problems of the image of the city of Vilnius and the role of its urban heritage. 


\section{LITERATURE REVIEW}

Each modern city strives to create its own image. Many scientific papers have extensively analyzed the process of city image formation: what determines one image or another, and how a certain imagination of particular objects and entities or phenomena appear in people's minds and in public space. (Pompe, 2019). An image is defined as the result of a perceptual process, as the formation of a set of certain qualities in the consciousness of each individual, thus the image will always be formed through experience (Anholt, 2007). The image of a city is often created unconsciously, as people sometimes memorize details such as the road, a shape, or a landmark that forces them to make specific decisions (Prapiestienè and Ucinavičiūte, 2017). The image of each place is highly influenced by heritage and history, which are not created in one day or night. Therefore, people have many different opinions about the city, which differ when comparing locals and tourists. In order to attract as many tourists and business investments as possible, cities need to compete with each other and show their uniqueness. (Kotler, et al., 2004)

Scientific literature states that the image of a city is associated with its brand and identity. The city's brand demonstrates the city's uniqueness in the world, and its identity allows people to associate it with certain places or events that do not allow it to be confused with other cities. Both of these factors are also addressed in the local image assessment model. Based on it, two groups that affect the image of the city are distinguished: attention-grabbing factors and grabbing-for-attention factors, which consist of different elements. (Prapiestiene and Ucinavičiūtè, 2019) (Fig. 1)

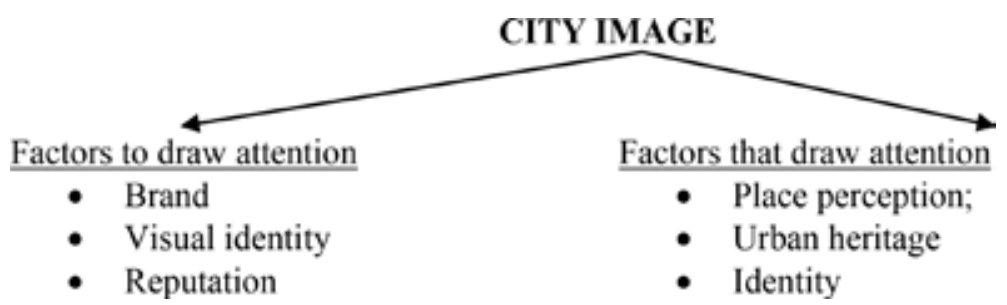

Fig. 1 Factors influencing the assessment of the image of a city

The above model includes two groups of factors. The first concerns expanding information not only within the city, but also outside it, as information is transmitted through the media, by taking photos, promoting the city, creating brands. The second group, on the other hand, is concerned with people's sense of place, i.e., how long a person has been in a particular place and whether they are able to get to know the place, or whether their opinion is formed in a very short time and only by seeing attractions.
According to Kotler (2004), there are numerous factors that shape the image of a city:

- physical quality of the environment - what makes the city unique, i.e., its architecture, historical heritage and landscape;

- social quality of the environment what variety of goods and services is provided and what the possibilities of communication are; 


\section{Journal of Contemporary Management Issues}

- society's values and material opportunities - what the skills and material needs of environmental assessment are and what material well-being is sought;

- virtual image of the environment - in what ways people receive information, how aware they are of city symbols and signs.

All of the above factors affect people's perceptions of the city and it is up to the city administration and the funds allocated to determine whether the image will be changed or the existing one maintained (Kirvaitienè, 2004).

Creating a local image has two objectives: to shape the city image as an attractive commodity, an offer to certain stakeholder groups, and to ensure the visibility on the external market, thereby reinforcing the local identity from within, linking the place to its stories. This kind of stakeholder interface, acclimatization to the place, allows gaining an advantage in competing against other cities (Warnaby and Medway, 2013).

Kavaratzis and Kalandides (2015) propose not to divide the city's target image audiences into more important and less important ones. It is most effective to involve as many stakeholders as possible in both the image building strategy and the target groups. When aiming at various and very different groups, the image campaign plan itself becomes significantly more difficult, but it brings out different sides of the city - it is multifaceted and has its own characteristics, according to each stakeholder group. When it comes to shaping the image of a city through urban heritage, it is worth noting that the image of a city improves the demographic, social and economic situation of each city's inhabitants. Urban elements that create the overall image of the city, but also the objects of urban heritage, reveal the uniqueness of the city, testify to its historical and cultural value. "Global architecture and the history of cities show that the architecture of buildings and the urban structure of cities have been symbols for many centuries, helping to convey the image of individuals and institutions, and in recent centuries - to attract more residents and visitors" (Kavaratzis \& Kalandides, 2015). Scientists particularly emphasize the importance of urban heritage objects, their comprehensive value - "those parts, elements and forms of the plan, building, volume and spatial composition that are significant for the development of the entire urban heritage or its individual objects and its peculiarities; that determine and give meaning to the maturity and originality of the composition of heritage objects" (Šćitaroci et al., 2019).

Thus, the formation of a coherent image of a city is complicated by the different characteristics of its territories, general social tendencies, and distinctive features of the city. Therefore, every city involved in global economic processes is forced to solve not only its identity, but also uniqueness tasks. In shaping the image of the city, urban identities face changes in their physical environment (places, objects), and the concept of distinction is heavily influenced by changes in the urban environment (community life models, interpersonal relationships, social norms) (Butkus, 2011). When considering the urban form of a city, it is important to understand its effect on the culture initiatives. The city has a visual impact on people: it is an art of interrelationship between architecture and man. The purpose of this art is to create an urbanized environment by using natural elements, buildings, communication and other components (component parts of the urban form of the city) in such a way that 
by interconnection they create a unique impression (Ivanauskaitè, 2015).

Rainisto (2003) introduced a system consisting of the factors that guarantee a successful formation of the city image:

1. Planning group refers to the authority or organization responsible for the planning and execution of the marketing plan;

2. Vision and strategic analysis (insights into the future vision of the representatives of the city);

3. Place identity and image (a unique set of local attributes and associations that image makers want to create or maintain);

4. Public and private sector partnership and leadership (the ability to run complex processes and gain organizational power).

These are the factors that reflect the city. There are four other success factors that help to solve the problems that arise when implementing an image building plan.

1. Political unity (smooth arrangements in public affairs);

2. Smooth operation in the global market;

3. Local development and prominent events (significant events or initiatives throughout the image-building process) (Rainisto, 2003).

In conclusion, it is important to emphasize that the urban heritage environment of a city directly influences its image. In order to form the desired image of a city, it is necessary to analyze the existing image and opinions and compare the results with the expectations. This kind of image matching assessment allows the creation of an effec- tive image building strategy. Although there are many stakeholders involved in building the image of a city, cities tend to focus on economic power and benefit groups such as tourists and business entities.

\section{METHODOLOGY}

A qualitative study was conducted in order to analyze the specific case of the influence of urban heritage on the image building of Vilnius. The interview method was applied in the research: 11 interviews were conducted.

The interview consisted of 15 open-ended questions. The questions mostly focused on these sections: (1) city image creation factors; (2) the perception of image creation (3) stakeholders of city image formation; (4) the impact of the urban heritage (initiatives). The questions were prepared according to the literature review.

These interviews can be referred to as expert interviews when evaluating informants' competencies. Informants were selected by non-random selection method, based on personal preference and reasoning. The experts were also selected on the basis of their long-term interest in the topic and the links between their personal competences and the nature of their work with the topic in question. (See Table 1). The aim was to reveal the broadest possible context of expert opinions. 


\section{Journal of Contemporary Management Issues}

Table 1. List of qualitative research experts and justification of their competence

\begin{tabular}{|c|c|c|}
\hline & Description & Justification of their competences \\
\hline Expert No. 1 & Professional urbanist & $\begin{array}{l}\text { One of the most active experts in Vilnius urban planning. } \\
\text { She analyzes the relationship between heritage and modern } \\
\text { construction. }\end{array}$ \\
\hline Expert No. 2 & $\begin{array}{l}\text { Head of the Department } \\
\text { of Urbanism, Faculty of } \\
\text { Architecture, VGTU, architect }\end{array}$ & $\begin{array}{l}\text { Works for the commission of the Vilnius city urban } \\
\text { projects selection. He has also arranged the architectural } \\
\text { process of the city and evaluates them. }\end{array}$ \\
\hline Expert No. 3 & $\begin{array}{l}\text { Architectologist researcher } \\
\text { of modernist ideology, } \\
\text { interactions of architecture and } \\
\text { politics, modernist heritage }\end{array}$ & $\begin{array}{l}\text { An expert in city architecture and heritage, as a member of } \\
\text { the architectural community familiar with the processes, } \\
\text { taking place in Vilnius. This expert was chosen as a source } \\
\text { of alternative information, i.e. an individual, who would } \\
\text { directly be involved in Vilnius urban planning. }\end{array}$ \\
\hline Expert No. 4 & $\begin{array}{l}\text { Tourism Department of } \\
\text { Vilnius, Project Manager }\end{array}$ & $\begin{array}{l}\text { A representative of the main organization, currently } \\
\text { operating and directly related to the formation of the city } \\
\text { image of Vilnius. }\end{array}$ \\
\hline Expert No. 5 & Guide in Vilnius & Vilnius city researcher, guide. \\
\hline Expert No. 6 & Guide in Vilnius & Vilnius guide to non-traditional routes around Vilnius. \\
\hline Expert No. 7 & Guide in Vilnius & Vilnius storyteller, guide, journalist. \\
\hline Expert No. 8 & $\begin{array}{l}\text { Architect, member of the } \\
\text { State Commission for Cultural } \\
\text { Heritage }\end{array}$ & $\begin{array}{l}\text { An architect with many years of experience, a member } \\
\text { of the State Cultural Heritage Commission. Information } \\
\text { obtained from this expert is directly related to heritage } \\
\text { protection issues. }\end{array}$ \\
\hline Expert No. 9 & $\begin{array}{l}\text { Architect in the architect firm } \\
\text { "DO Architects" }\end{array}$ & $\begin{array}{l}\text { Architect, who reflects the current insights of young } \\
\text { architects of Vilnius and has an opinion of the relationship } \\
\text { between heritage and modernity in the city. }\end{array}$ \\
\hline Expert No. 10 & $\begin{array}{l}\text { Head of the real estate services } \\
\text { company "Ober-Haus" }\end{array}$ & Real estate market expert. \\
\hline Expert No. 11 & $\begin{array}{l}\text { Leader of the Žverynas } \\
\text { community, heritage protection } \\
\text { activist }\end{array}$ & $\begin{array}{l}\text { A representative of the community of Vilnius city, as well } \\
\text { as an active defender of the interests of the residents of the } \\
\text { entire city and an enthusiast of heritage conservation. }\end{array}$ \\
\hline
\end{tabular}

Seven of the eleven interviews were conducted through face-to-face interviews and the other four by phone. All of them were in-depth interviews, conducted by a single interviewer. The meetings and telephone interviews were semi-structured, i.e. those interviews were based on pre-prepared questions, but their order, wording and scope vary according to the interview process and the informant's own field of activity.

The interviews were conducted in two stages. First, six broader interviews were conducted, analyzing each expert's perspective on the image of Vilnius, the relationship of his/her neighbourhood(s) with the overall 
urban identity, culture initiatives and the key components that determine the city's image. After these interviews, the links between the city image and the urban heritage were investigated. Then, five more interviews were conducted. In these second-stage interviews with the informants, specific neighbourhoods of Vilnius were discussed in more detail: their image, the situation of heritage sites, and the overall relationship within the city as a whole. The study was conducted in November 2019. In order to ensure that ethical requirements are met, the principle of the research participants' free will to participate in data collection was applied and they were not offered anything in return. During the interviews, an attempt was made to remain in a neutral position, not to evaluate the participants themselves, but natural responses were given to the informants' emotions by expressing their opinion. To avoid a situation where participants say something during the interview that they do not want to be publicly published, but is useful and necessary for the study, each informant was asked whether they agreed that the recording of the interview and all the thoughts expressed during the interview are used for scientific purposes.

\section{SITUATION ANALYSIS OF URBAN HERITAGE INITIATIVES FOR VILNIUS CITY IMAGE FORMATION}

Vilnius city image formation is regulated by the General Plan (BP) of the Vilnius City Municipality that states that "the unique landscape of Vilnius is characterized by the general structure of the city plan, the network of streets and squares, parts of the city centre and historical suburbs formed by different principles and distinctive details of urban structure classicist style building complexes, modern architectural buildings of the $20^{\text {th }}$ and $21^{\text {st }}$ centuries on the right bank of the Neris, surrounded by natural, forested slopes formed by the Ice Age River" (Vilnius City Municipal Council, 2019). The image of Vilnius city is multi-dimensional. There is the historical city, Vilnius is also an artistic city, there is also an innovative - alternative city that is interesting for young people. The image of Vilnius is communicated as a small, green, historical, artistic and at the same time - modern city. Investors also take into account the ratings, where Vilnius goes up and focus on qualified employees, who come here to live. In the previously mentioned documents and in the $G O$ Vilnius city representation strategy, the feature of modernity is singled out. Summarizing the innovative processes that are attractive to the target image groups, Vilnius has been named a modern city.

In 2014, at the request of the Vilnius City Municipality Administration, UAB Lukrecijos reklama conducted a study to improve the city's image, in order to facilitate the identification of shortcomings in the image and its formation process and to take effective actions to help create an innovative city image. The study report states that the "three essential features of the Vilnius brand have been refined - romance, refreshment, progress. These three features usually reach the consumer as a set, he "tastes" everything little by little and as a result gets an unexpected experience in Vilnius" (Lukrecijos reklama, 2014: 4).

The study also included suggestions on the improvement of the city's image strategic goals, related to the preservation of heritage:

1. Catalyse the growth of tourism flows and seek higher revenues from tourism flows;

2. Increase Vilnius' international recognition and brand value;

3. Use the available potential of Vilnius: 


\section{Journal of Contemporary Management Issues}

- natural distinctiveness;

- technological advantage;

- historical heritage;

- the advantage of the capital (Lukrecijos reklama, 2014: 5).

It is worth noting that the historical heritage is singled out as one of the potential elements of urban identity.

It is agreed that Vilnius' historical, as well as urban heritage is a value. It needs to be nurtured because it, along with other elements, shapes the image of the city. The process of heritage preservation and values are also regulated by the Law on the Protection of the Real Cultural Heritage of the Republic of Lithuania and the Law on Architecture of the Republic of Lithuania. It states that "the goal of architectural development is high architectural quality, which determines the well-being, sustainable environment of the state and people, promotes economic growth and cultural progress, improves the image of the state" (Parliament of the Republic of Lithuania, 2017). One of the directions of architectural development is the aspiration to "protect and develop the immovable architectural, urban and ethnocultural heritage" (Parliament of the Republic of Lithuania, 2017).

The main measures in solving the problems of the urban structure of Vilnius city:

1. further develop the city centres (the main city centre and the local city centres), to form their mixed functional structure and compact construction;

2. give priority to the internal development of the city, secondary use (conversion) of territories, modernization, construction of unfinished quarters (in the central and middle zones of the city - in the zones of the main centre, part of the city centre, as well as in Soviet-era intensive residential areas):
2.1. use abandoned, inefficiently used areas and develop urban heritage initiatives within them.

3. form complete, high-quality building structures and public spaces, promote the conversion of inefficiently used territories, the multifunctionality of land use (Vilnius City Municipality Council, 2019).

In Vilnius, the issues of how to effectively coordinate the protection of cultural values and the renewal of the city with urban initiatives are still in progress. The city municipality does not have a specific official document explaining the strategy of creating the image of the city of Vilnius. Vilnius City Strategic Development Plan for 20102020 defines goals - to form a modern, prosperous city of Vilnius, with the status of the Northern European economic center. Others argue that the plan should be detailed or supplemented.

The General Plan (BP) of the Vilnius City Municipality develops suggestions for the conversion of brownfields and the maintenance of the central part of the city. Those areas that have the greatest impact on the city's image are prioritized. Conversions are often inefficient, because protected heritage sites are maintained and modified by their individual managers and there are no strategic plans. However, informants stress that there is no way to push businesses or entities willing to invest and that compromises must be sought. The authors do not support the preservation of absolute heritage sites; they all agree that a balance between innovation and the nurturing of old values is necessary.

\section{RESULTS AND DISCUSSION}

Comparing the situation of the city of Vilnius with the cities in other countries, the general tendencies of contradictions between the development of urban heritage 
and new constructions are similar. It is often the old towns and the central parts of the town that are the focus of such research and public debate. The need to preserve urban heritage features in such urban areas has been under discussion for decades. In the old towns, new architecture buildings are rapidly growing and will grow as old worn-out buildings need to be renovated. If all of them contrast with the historical environment, instead of the old historical view of the city, one can see a modern cityscape with one another building of modern architecture. It will not be an old historical, protected cityscape, but something new (Daniulaitis, 2003).

More than a decade ago, specialists in their assessment of Vilnius's urban development processes said that Vilnius was represented by the revitalized Old Town, the new centre with high-rise buildings on the right bank of the Neris, Konstitucijos Avenue, newly created knowledge economy clusters, new jobs in modern urban business, entertainment and shopping centres, improving environmental quality and liberating individuals. As in a democratic society, city dwellers and businesses not only actively invest in urban development, but also discuss the future of the city: "new and old" harmony, urban development policy, the quality of life standards and their compliance with old European traditions (Bardauskienè, 2006)

The distinctive image of Vilnius is formed by the general structure of the city plan, the network of streets and squares, the different parts of the city centre and historical suburbs and the distinctive details of the urban heritage, but also by the experts' opinions (Table 2).

Table 2. Perceptions of city image formation for Vilnius

\begin{tabular}{|c|c|c|}
\hline Category & Subcategory & Expert/ Quote \\
\hline \multirow{6}{*}{$\begin{array}{l}\text { City image } \\
\text { perception }\end{array}$} & $\begin{array}{l}\text { Multiple image of } \\
\text { the city }\end{array}$ & $\begin{array}{l}\text { Expert 4: "...Vilnius is a historic city, as well as artistic and } \\
\text { innovative - an alternative city that is interesting for young people. } \\
\text { The image of Vilnius is formed as a small, green, historical, artistic } \\
\text { and at the same time a modern city". }\end{array}$ \\
\hline & Metropolis & $\begin{array}{l}\text { Expert 4: "Vilnius is an innovative, international and prosperous } \\
\text { economic centre in Northern Europe with happy and friendly } \\
\text { inhabitants, colourful cultural life, neat and safe environment } \\
\text { (Vilnius City Municipality Council, 2017)". }\end{array}$ \\
\hline & Modern city & $\begin{array}{l}\text { Experts } 5,1 \text { : The vision of a modern city is formed in the strategy } \\
\text { of urban development. }\end{array}$ \\
\hline & Conservative city & $\begin{array}{l}\text { Experts 3, 6: "All technical, and urban innovations, city } \\
\text { infrastructure development innovations arrived to Vilnius quite } \\
\text { late. Here one can mention the horse tram, the water supply system, } \\
\text { the public transport. This shows not modernity, innovation, but } \\
\text { conservatism". }\end{array}$ \\
\hline & $\begin{array}{l}\text { No clearly defined } \\
\text { city image }\end{array}$ & $\begin{array}{l}\text { Expert 5: "This was due to natural causes: Vilnius does not have } \\
\text { a clear identity due to its diverse and complicated history. Many } \\
\text { periods, with a rich cultural and heritage legacy, but it is difficult to } \\
\text { single out one". }\end{array}$ \\
\hline & $\begin{array}{l}\text { No vision for a } \\
\text { specific city }\end{array}$ & $\begin{array}{l}\text { Expert10: The municipality of Vilnius should not, in general, create } \\
\text { a very specific integral image. He notes that the image created by } \\
\text { the inhabitants themselves, the movement of the city, the cultural } \\
\text { life - that is the essence. Artificially this will not happen. }\end{array}$ \\
\hline
\end{tabular}




\section{Journal of Contemporary Management Issues}

In 2014, Vilnius City municipality carried out an urban image improvement study, which helped to highlight the three essential features of the Vilnius city brand: romanticism, recreation, progress. These three properties usually reach the user as a set. The image pursuit is directed toward different stakeholders of the Vilnius city image:

1. Foreign tourists: an unexpected opportunity to get more than expected: historically rich city; modernity and romance; European quality at an attractive price; comfort and greenery; relaxation from stress.
2. Business: Unexpectedly good business conditions: high-end offices and hotels; fast communication; high-quality leisure - high class cultural events; opportunity to reach nature within a dozen minutes from the city.

3. Population: more opportunities to work, do business and live than in other cities of Lithuania; many different events for different tastes ("Lukrecijos reklama", 2014: 4).

Table 3. Expert opinions about the stakeholders of city image formation

\begin{tabular}{|l|l|l|}
\hline Stakeholders & City image & Expert/ Quote \\
\hline $\begin{array}{l}\text { For investors } \\
\text { and business } \\
\text { developers }\end{array}$ & Modern city & $\begin{array}{l}\text { Expert 2: "The concept of a modern city is more directed } \\
\text { towards the external context, international communicative } \\
\text { spaces". }\end{array}$ \\
\cline { 2 - 3 } For local residents & City of opportunities & $\begin{array}{l}\text { Expert 1: The potential of the city is perceived by business } \\
\text { developers through the range of services provided, through } \\
\text { the financial possibilities that can be realized in the city. }\end{array}$ \\
\hline importance & $\begin{array}{l}\text { Experts 1, 6, 8: The local residents usually have their own } \\
\text { associations, experiences with the city developed more } \\
\text { through personal experiences, so the creation of the city } \\
\text { image for them is not very important. } \\
\text { The city image should be created primarily for its } \\
\text { inhabitants, because the tourists, people coming for } \\
\text { business purposes are only episodic, while the satisfaction } \\
\text { and perception of what is your city is more necessary for } \\
\text { permanent residents. }\end{array}$ \\
\cline { 2 - 4 } & $\begin{array}{l}\text { Conservative image } \\
\text { For tourists and } \\
\text { visitors }\end{array}$ & $\begin{array}{l}\text { Expert 2: Conservative environment - it is clear and still } \\
\text { exists inside the city. }\end{array}$ \\
\hline $\begin{array}{l}\text { Romantic image of the } \\
\text { natural exclusivity; } \\
\text { technological advantage; } \\
\text { historical heritage; } \\
\text { capital advantage }\end{array}$ & $\begin{array}{l}\text { Expert 1: The places to visit and events in the city create } \\
\text { their own images, and perhaps the image that is created for } \\
\text { them in advance also formulates the expectations. }\end{array}$ \\
\hline
\end{tabular}

Finally, the experts were asked how they value the heritage initiatives. Expert 6 emphasizes that Vilnius is an interesting urbanistic initiative,e not in its modernity, but in its past and conservatism. No matter how hard one tries to show that Vilnius is a modern city, it will not be attractive to its guests, tourists and residents of Vilnius. However, Expert 4 opposes, pointing out that heritage must not only be protected, but also benefit from the present. Modern buildings will attract more people, businesses 
and the city itself will recover, as people and capital come. The arguments of most experts lead to the conclusion that modern Vilnius cannot be formed without presentday buildings and at the same time cannot remain unique, if significant conversions of heritage objects are carried out.

Summarizing the opinions of experts, it can be stated that experts are sceptical about the application of the concept of a modern city in shaping the image of Vilnius, as many say it is inappropriate for this city. Others argue that the concept of modernity should be elaborated, or supplemented with the elements of urban heritage initiatives. Experts also differed on what the target audience for image building should be. Some argued that the focus should be on creating an attractive city image for the local population, rather than on the international image of the city. However, all the experts agreed that the cultural and heritage initiatives need to find a balance between innovations and the cherishing of old values to develop the image of Vilnius.

\section{CONCLUSIONS}

The analysis of previous research shows that a state or a city that wants to present itself in a competitive world market environment, needs a specific image, which is useful for consolidation of reputation and for increasing its recognition. But in today's world, discovering local distinctions is very difficult.

As the image of a place is formed through the individual's personal experience, it is important to form the image for well-defined target audiences. Many image makers are interested in attracting highperforming audiences to the area (city), so image campaigns are targeted at tourists or investors. The locals, who represent the city and spread the message about it are often overlooked, and, therefore, the image of the city should be made attractive to them, as well.

In the process of urban modernization, the confrontation between the preservation of culturally valuable urban heritage sites and the implementation of innovations is becoming bitter in many cities. Heritage is often damaged when new buildings are being built or old ones restored. Only a comprehensive urban planning process ensures heritage conservation, as it is usually focused on individual, concrete projects and their overall environmental impact is assessed casually, as a result of high rates of development worldwide.

The case of Vilnius city image formation is considered by experts to be inappropriate. The research showed that experts are sceptical about the application of the concept of modern city in shaping the image of Vilnius. The need of urban heritage and culture initiatives strategy were developed as they are essential for city image formation. The main image-building measures of Vilnius are aimed at target groups that bring the greatest financial gain: investors, tourists, business entities, potential employees. The aim of the image-building activities is to create an international rather than a local (for local residents) image of Vilnius.

The paper formulates the principles that justify the city image formation: influence of the urban heritage initiatives is seen as inevitable in city brand image formation and the forming the city image of Vilnius is recommended to maintain a balance between innovations and the cherishing of old values. 


\section{Journal of Contemporary Management Issues}

\section{References}

1. Anholt, S. (2007). Competitive Identity. The New Brand Management for Nations, Cities and Regions. Ebbw Vale: Creative Print \& Design.

2. Bardauskienè, D. (2006). Vilniaus urbanistikos savitumas Europos Sajungos kontekste. Acta Academiae Artium Vilnensis. 40, 17-28.

3. Butkus, T. S. (2013). Lietuvos urbanistika: diskurso problema ir raidos perspektyvos. Acta Academiae Artium Vilnensis. 71, 47-58. http:// leidykla.vda.lt/Files/file/Acta_71/ Acta_71_03_T_Butkus_48_58p.pdf

4. Butkus, T. S. (2011). Miestas kaip ivykis. Urbanistine kultūriniu funkciju studija. Kaunas: Kitos knygos.

5. Ci, Cunhyeong ir Choi, Sujin (2017). How to manage a city's image using the brand concept map and network analysis: a case of Seoul. Quality \& Quantity. 51(6), p2441-2456. 16p. doi: 10.1007/s11135-016-0402-6

6. Daniulaitis, G. J. (2003). Miestovaizdis ir jo projektavimas. Urbanistika ir architektūra, 27(1), 3-11.

7. Daunora, Z. J., Kirvaitienè, S., ir Vyšniūnas, A. (2004). Vilniaus miesto vizualinio identiteto apsauga ir pletros principai. Vilnius: Technika.

8. Drūteikienè, G. (2007). Organizacijos ivaizdžio valdymas. Vilnius: Vilniaus universiteto leidykla.

9. Drūteikienè, G., ir Marčinskas, A. (2010). Universiteto ịvaizdžio kaita. Monografija. Vilnius: Vilniaus universiteto leidykla.

10. Giddens, A. (2005). Sociologija. Kaunas: UAB „Poligrafija ir informatika".

11. Ivanauskaitè, A. (2015). Miesto urbanistinès formos samprata ir jos taikymo galimybės Lietuvoje, Mokslas - Lietuvos ateitis, 7(1), 46-54. https:// doi.org/10.3846/mla.2015.711

12. Ham, P., (2008). Place Branding: The State of the Art. The ANNALS of the American Academy of Political and Social Science. 616, 126-149. https:// doi .org/ 10.1177/0002716207312274

13. Horlings, L. G., (2015). Values in place; A value-oriented approach toward sustainable place- shaping. Regional Studies, Regional Science. 2(1), 257-274. https://doi.org/ 10.1080/21681376.2015.1014062

14. Jurevičienè, J. (2013). Kraštovaizdžio kultūrinè vertè: išsaugojimo principai. Vilnius: Technika.

15. Kačeraukas, T. ir Kaklauskas, A. (2014). Kūrybinis miestas: mitai ir utopijos. Filosofija. Sociologija, 25(3), 196-197

16. Kavaratzis, M. (2005). Place Branding: A Review of Trends and Conceptual Models. The Marketing Review, 5(4), 329-342. doi:10.1362/146934705775186854

17. Kavaratzis, M., Hatch, M. (2013). The dynamics of place brands: An identitybased approach to place branding theory. Marketing Theory. 13(1), 69-86. doi:10.1177/1470593112467268

18. Kavaratzis, M., Kalandides, A. (2015). Rethinking the place brand: the interactive formation of place brands and the role of participatory place branding. Environment and Planning A: Economy and Space. 47(6), 13681382. https://doi.org/10.1177/0308518 X15594918

19. Kirvaitienè, S. (2007). Miesto įvaizdžio formavimo galimybès ir uždaviniai plètojant centro aplinka https://vb.vgtu. 1t/object/elaba:2016548/2016548.pdf 
20. Kotler P., Nebenzahl, I., Lebedenko, V. et al. (2004) Opinion Pieces „Where is place branding heading?" Place branding, 1, 11-15.https://www.researchgate. net/publication/247478341_'Where is_place_branding_head ing'

21. Langer, R. (2000). Place images and place marketing. Dalgas Have 15. https://openarchive.cbs.dk/bitstream/ handle/10398/7721/langer_place. pdf?sequen

22. Lukrecijos reklama. (2014). Vilniaus miesto ìvaizdžio tobulinimo studija. https://vilnius.lt/wp- content/uploads/2018/07/VMSA_Vilniaus ivaizdzio_tobulinimo_studija_III\%20 etapas.pdf

23. Marconi, J. (1997). Imagine Marketing: using public perceptions to attain business objectives. Illinois: NTC Publishing Group.

24. Obad Šćitaroci, M, Bojanić Obad Šćitaroci, B., Mrđa, A. (2019). Cultural Urban Heritage: Development, Learning and Landscape Strategies. Springer; 1st ed. 2019 edition.

25. Pompe A. (2019). Designing the image and the perception of the city and its' brand: the importance and impact of qualitative urbanistic elements. Advances in Business-Related Scientific Research Journal, 10(2), 2019
26. Rainisto, K. S. (2003). Success factors of place marketing: a study of place marketing practices in Northern Europe and the United States http://bestplaceinstytut.org/www/wp-content/uploads/2010/10/dissertationRainisto.pdf

27. Rakytová, I.,Tomčíková, I. (2019). Using UNESCO World Heritage Site of Vlkolínec (Slovakia) in Geographical Education. Review of International Geographical Education Online. (RIGEO), 9(2),426-446 doi:10.33403/ rigeo. 573655

28. Slater, D., ir Tonkiss, F. (2001). Rinkos visuomene. Vilnius: Lietuvos rašytojų sajungos leidykla.

29. Vilniaus miesto savivaldybès Teritorijų planavimo komisija. (2019). Vilniaus miesto savivaldybès teritorijos bendrasis planas. Aiškinamasis raštas. (2019, rugsèjo 13, Nr. 30- 614). https://vilnius.lt/wp- content/uploads/2019/09/ Vilniaus_BP_Sprendiniai_Aiskinamasis_rastas_tvirtinti_2019_09 13.pdf

30. Warnaby, G., \& Medway, D. (2013). What about the 'place' in place marketing? Marketing Theory. 13(3) 345-363. doi: $10.1177 / 1470593113492992$

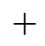




\title{
Journal of Contemporary Management Issues
}

\section{STVARANJE IMIDŽA GRADA KROZ INICIJATIVE URBANOG NASLIJEDA}

\author{
Miglè Černikovaité \\ Žaneta Karazijiené
}

\section{Sažetak}

U današnjem svijetu, dok se gradovi natječu na tržištu, strategije stvaranja imidža nekoga grada često se izrađuju samo kako bi se udovoljilo težnjama za profitom, poslovnim razvojem i osviještenosti. Očuvanje kulture, te povijesne i urbane baštine ostaje važno samo unutar strategija urbanog razvoja, a ne i prilikom stvarnog djelovanja usmjerenog na razvoj. Istina je da sliku grada oblikuju različiti povijesni, politički, demografski, sociološki i ekonomski čimbenici koji čine ono što doživljavamo kao imidž grada. Međutim, jedan od najuočljivijih elemenata imidža grada je urbana baština utemeljena na nacionalnoj tradiciji. Cilj ovoga članka je procijeniti učinke inicijativa urbanog naslijeđa u stvaranju imidža grada Vilniusa. Prilikom istraživanja korištene su kvalitativna analiza sadržaja i polustrukturirani intervjui sa stručnjacima. Glavni zaključci potiču raspravu, oklijevanje i kritiku od strane zajednica i istraživača grada koji koriste nove objekte baštine i kulturne inicijative kako bi stvorili imidž grada Vilniusa. Utjecaj urbane baštine neizbježna je sastavnica prilikom oblikovanja imidža grada Vilniusa, ali još uvijek nema učinkovitih strategija koje bi se bavile novim inicijativama urbane baštine pri stvaranju imidža grada Vilniusa.

Ključne riječi: imidž grada, inicijative urbanog naslijeđa, modernizacija, mjesta baštine, dionici, urbane četvrti, razvoj poslovanja. 